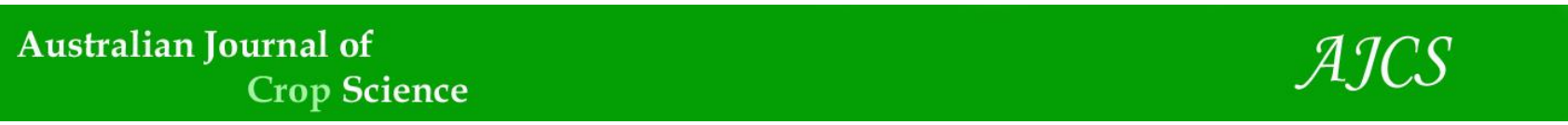

AJCS 15(03):464-469 (2021)

ISSN:1835-2707

doi: 10.21475/ajcs.21.15.03.p2526

\title{
Selection of high-performance black-eyed cowpea (Vigna unguiculata) through GYT biplot analysis: a new methodology based on multiple characteristics
}

\author{
Kleberson Cordeiro Araújo ${ }^{1}$, Tâmara Rebecca Albuquerque de Oliveira*, Geraldo de Amaral Gravina ${ }^{1}$, \\ Maurisrael de Moura Rocha ${ }^{2}$, Francisco de Alcântara $\mathrm{Neto}^{3}$, Gustavo Hugo Ferreira de Oliveira ${ }^{4}$, Derivaldo \\ Pureza da Cruz ${ }^{1}$, Camila Queiroz da Silva Sanfim de Sant'Anna ${ }^{1}$, Lilia Marques Gravinaa ${ }^{1}$, Richardson Sales \\ Rocha $^{1}$, Israel Martins Pereira ${ }^{1}$
}

\author{
${ }^{1}$ Universidade Estadual do Norte Fluminense Darcy Ribeiro (UENF), Brasil \\ Campos dos Goytacazes, 28013-602, RJ, Brasil \\ ${ }^{2}$ Embrapa Meio-Norte, Av. Duque de Caxias, 5650 - Buenos Aires, 64006-245, PI, Brasil \\ ${ }^{3}$ Universidade Federal do Piauí, Bairro Ininga, 64049-550, PI, Brasil \\ ${ }^{4}$ Universidade Federal de Sergipe (UFS), Campus do Sertão, Nossa Senhora da Glória, 49680-000, SE, Brasil
}

*Corresponding author: tamara_rebecca@hotmail.com. ORCID: 0000-0003-4418-1547.

Abstract

Cowpea bean is a common crop quite appreciated in Brazil. However, it is known that its low yield depending on soil and climatic conditions. The aim of this research is the selection of high-performance black-eyed cowpea through GYT biplot analysis. Twelve (12) cowpea bean strains were assessed between 2016 and. The study followed a randomized complete block design, with four repetitions; two commercial cultivars were used ascheck. The following variables were assessed: number of days required for flowering, final stand, value for cultivation, pod yield, pod length, mean number of grains per pod and grain weight. The analysis of variance showed genetic variability between strains, differences between the assessed years and different strain-performance in each growing year. Based on the GYT biplot graph, cultivar BRS Itaim, and strains L9 and L7 recorded the best performance for the set of yield characteristics. Variable 'pod length' had positive correlation to bedding, number of days required for flowering and number of grains per pod. Variable '100-grain weight' had positive correlation to final stand, pod yield and mean grain weight per pod. Strains L9, L7 and cultivar BRS Itaim recorded the best yield regarding the assessed variables.

Keywords: Trait associations; Vector view; Vigna unguiculata (L.) Walp.

Abbreviations: GY/LD_Grain Yield/Lodging; GY*CV_Grain Yield/Crop Value; GY/NDF_Grain Yield/Days Required for Flowering; GY*PL_Grain Yield*Pod Length; GY*PS_Grain Yield*Final Plant Stand; GY*PY_Grain Yield*Pod Yield; GY*NGP_Grain Yield*Number of Grains Per Pod; GY*GWP_Grain Yield*Weight of Grains Per Pod; GY*W100G_Grain Yield*Weight of 100 Grains.

Introduction

Different bean species are cultivated in Brazil; however, only cowpea (Vigna unguiculata L.) and common beans (Phaseolus vulgaris L.) are considered beans for consume (MAPA, 2010; Freire Filho, 2011). According to IBGE (2017), Brazil has approximately 3.1 thousand hectares cultivated with beans and ranks third place in the world production rank, given its mean production of $1.083 \mathrm{~kg} \mathrm{ha}^{-1}$. Cowpea bean is a leguminous rich in protein, minerals, amino acids, carbohydrates, vitamins and fibers (Bomfim-Silva et al., 2018). Brazilian cowpea crops do not reflect the plant's yield potential, since the species is vulnerable to broad soil and climatic changes. Although producers choose cultivars of interest to the market, cowpea bean plants present different performance depending on the soil and climate conditions. Thus, recommendations for cultivars presenting good performance in characteristics of interest to consumers, and high-performance, consider the management system the crop will be subjected (Santos, 2013). According to Yan and Frégeau-Reid (2018), the new GYT biplot multivariable analysis is the most indicated to select genotypes presenting both high yield and other characteristics of interest, since this methodology takes into account the mean yield characteristics, i.e., mean values resulting from the yield/other variables combination. Besides, this analysis allows better understanding the correlations between the assessed characteristics, and their simultaneous selection. The awareness about the association between variables is relevant for enhancement programs, mainly when the genotype presents characteristics of difficult selection (Cruz, 2014). The aim of this study was to select the highperformance black eyed cowpea (Vigna unguiculata L.) through GYT biplot analysis.

Results and discussion

\section{Analysis of variance}

Coefficient of variation (CV\%) results were lower than $30 \%$ in the assessed variables, except for bedding (LD), pod length 
(PL) and grain yield (GY) (Table 2). Based on the classification by Pimentel-Gomes and Garcia(2002), CVs\% values below, or equal to, $30 \%$ indicate highly accurate experiment. Quantitative variables often record high coefficient of variation values, since they are highly influenced by the environment. Soil and climate differences were indicated by significant results recorded for each assessed year. However, significances between strains and the strain by year interaction pointed towards strain genotypic variance and different yield rates in each assessed year. Thus, indicating the high reliability of results from multivariate analyses.

Different performances recorded for the assessed variables, except for LD, justify the evaluation of this selection of enhanced materials. Besides, such performances subsidize the understanding about the existing correlations between the assessed set of yield characteristics.

\section{GYT biplot analysis}

The GYT biplot analysis, which represents the mean performance of cowpea bean strains, explained the $88.43 \%$ total variation in the set of assessed yield characteristics (Figure1). This result allows safe and efficient strain selection through biplot analysis (Yan, 2011).

Perpendicular lines in the GYT biplot graph divide the groups and their respective vertices, which are the farthest points from the origin. Strains at the vertices present the best performance in the set of yield variables in each group. Strains inside the polygon are the least responsive to environment stimuli (Yan and Frégeau-Reid, 2018; Oliveira et al., 2919; Yan, 2001). Accordingly, the set of yield variables in the same group are similar in their response to the environment; thus, it is possible selecting the variable that best represents the group.

Based on the aforementioned, it was possible observing three traits groups (MEGA- TARGET-TRAITS), one was formed by the complex of GY/LD, GY*CV, GY/NDF and GY*PL combinations, second one was formed by GY*NGP, GY*GWP and $G Y^{*} P Y$ and the third one encompassed for GY*PS and GY*W100G. Strain L9 was located in one of the vertices of the polygon in MEGA- TARGET-TRAITS 1 , it was the most favorable for that group, as well as Strain L7 in MEGATARGET-TRAITS 2. The cultivar BRS Itaim has the best response in MEGA- TARGET-TRAITS 3. Thus, these genotypes accomplish the highest yields in at least one of the environments tested and they are among the lines presenting the best performance in the other traits composing the groups.

As the MEGA- TARGET-TRAITS groups were formed by a combination of yield assessed and some other trait of importance, allowed the formation of ideal traits that should be take account to select the best line even when the yield is missing or unevaluated according to the breeding propose. MEGA- TARGET-TRAITS 1 was composed of traits that represent the "plant characteristics", MEGA- TARGET-TRAITS 2 comprised the most important aspect for selection, "pod characteristics" and the last one can be used for specific aim, based rise the performance on the field. Assumingly, the assessed genotypes were possible sources of alleles favorable for the increase the ability of yield in the environments tested. Finally, the genotypes in MEGATARGET-TRAITS 2 presented the potential to be used as parents in breeding programs aimed at increasing the frequency of favorable alleles through appropriate genetic breeding methods.
The success or efficient to the recombination of these strains lids to the knowledge of dominant or additive genetic expression related to these traits. Based on the literature, in

Table 1. Lines to be selected.

\begin{tabular}{lc}
\hline N. & Line Code \\
\hline 1 & MNC06-895-1 \\
2 & MNC06-895-2 \\
3 & MNC06-901-14 \\
4 & MNC06-907-29 \\
5 & MNC06-907-30 \\
6 & MNC06-907-35 \\
7 & MNC06-908-39 \\
8 & MNC06-909-52 \\
9 & MNC06-909-54 \\
10 & MNC06-909-55 \\
11 & MNC06-909-68 \\
12 & MNC06-909-76 \\
13 & BRS Itaim \\
14 & CB-27 \\
\hline
\end{tabular}

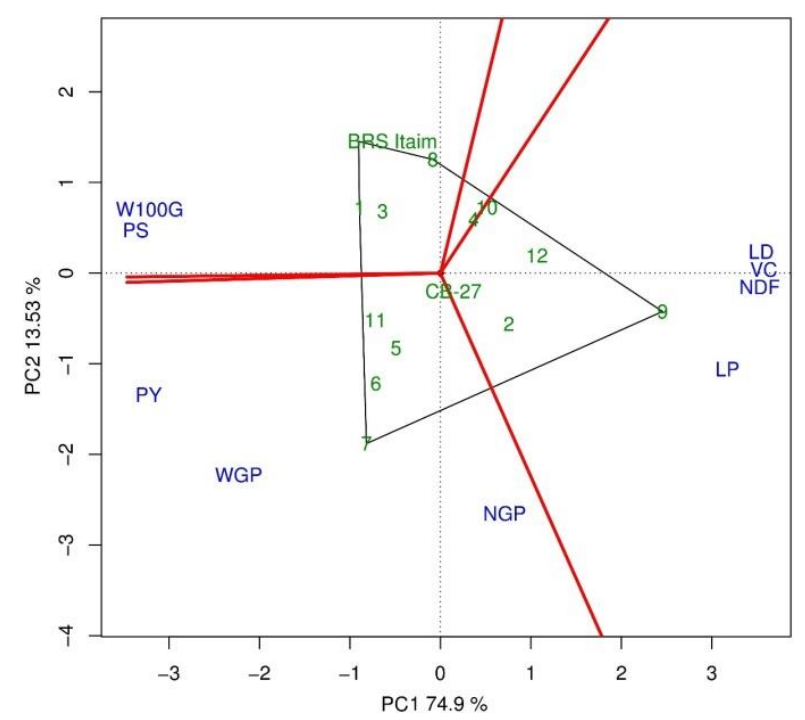

Fig 1. GYT Biplot representing "which-won-where" of the 14 cowpea lines, being NDF: number of days for flowering; PS: final plant stand; CV: crop value; LD: lodging; PY: pod yield; PL: pod length; NGP: number of grains per pod; WGP: weight of grains per pod; GY: grain yield; W100G: weight of 100 grains. Lines 1 (MNC06-895-1); 2 (MNC06-895-2); 3 (MNC06901-14); 4 (MNC06-907-29); 5 (MNC06-907-30); 6 (MNC06907-35); 7 (MNC06-908-39); 8 (MNC06-909-52); 9 (MNC06909-54); 10 (MNC06-909-55); 11 (MNC06-909-68); 12 (MNC06-909-76); 13 (BRS Itaim); 14 (CB-27).

the MEGA- TARGET-TRAITS 2 the additive effects are highly important for these traits in beans (Gonçalves, 2013; Santos, 2013; Coelho, 2017). When the genotypes give rise to the vertices of the polygon, but do not have any clustered traits, they are unfavorable for the groups of testes traits complex combination. This outcome reveals the low responsiveness and productivity of these genotypes. Thus, genotypes located in the sectors shall not be recommended as parents in breeding programs aim increasing the expression of the trait under stress or no stress condition. Lines L 4 and L10 can be considered inefficient and not responsive to any trait evaluated. 


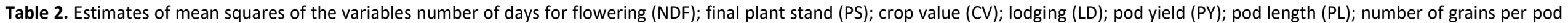
(NGP); weight of grains per pod (WGP); grain yield (GY); and weight of 100 grains (W100G) of 14 cowpea lines, assessed at Bom Jesus de Itabapoana Municipality, Rio de Janeiro State, Brazil.

\begin{tabular}{|c|c|c|c|c|c|c|c|c|c|c|c|}
\hline \multirow{2}{*}{ Sources of variation } & \multirow{2}{*}{ DF } & \multicolumn{10}{|l|}{ MS } \\
\hline & & NDF & PS & $\mathrm{CV}$ & LD & $\mathrm{YP}$ & $\mathrm{LP}$ & NGP & WGP & W100S & GY \\
\hline Block (Year) & 6 & 57.81 & 54.54 & 1.52 & 0.18 & 10.13 & 4.34 & 2.78 & 10.52 & 29.69 & 46.13 \\
\hline Years & 1 & $1056.57^{* *}$ & $121118.08^{* *}$ & 0.14 & $1.51 *$ & $872.49 * *$ & $20.89 * *$ & $243.67 * *$ & $464.12^{* *}$ & $96.01 *$ & $1867.64 * *$ \\
\hline Lines & 13 & $250.67 * *$ & $108.22 *$ & $1.94 * *$ & 0.63 & $17.61 * *$ & $21.02 * *$ & $11.76^{* *}$ & $11.71^{* *}$ & $33.49 *$ & $24.33^{*}$ \\
\hline Lines $x$ Years & 13 & $257.76 * *$ & 46.00 & $1.70 * *$ & 0.49 & $10.36^{*}$ & $20.41 * *$ & $6.16^{*}$ & 7.62 & $59.42 * *$ & 21.02 \\
\hline Error & 78 & 29.91 & 52.85 & 0.53 & 0.37 & 4.93 & 3.46 & 3.04 & 4.23 & 15.93 & 12.70 \\
\hline $\mathrm{CV}(\%)$ & & 9.74 & 24.22 & 22.54 & 39.27 & 15.94 & 41.46 & 17.59 & 18.18 & 18.21 & 58.83 \\
\hline
\end{tabular}

* and ** significant at 0.05 and 0.01 probability levels by $\mathrm{Ftest}$, respectively

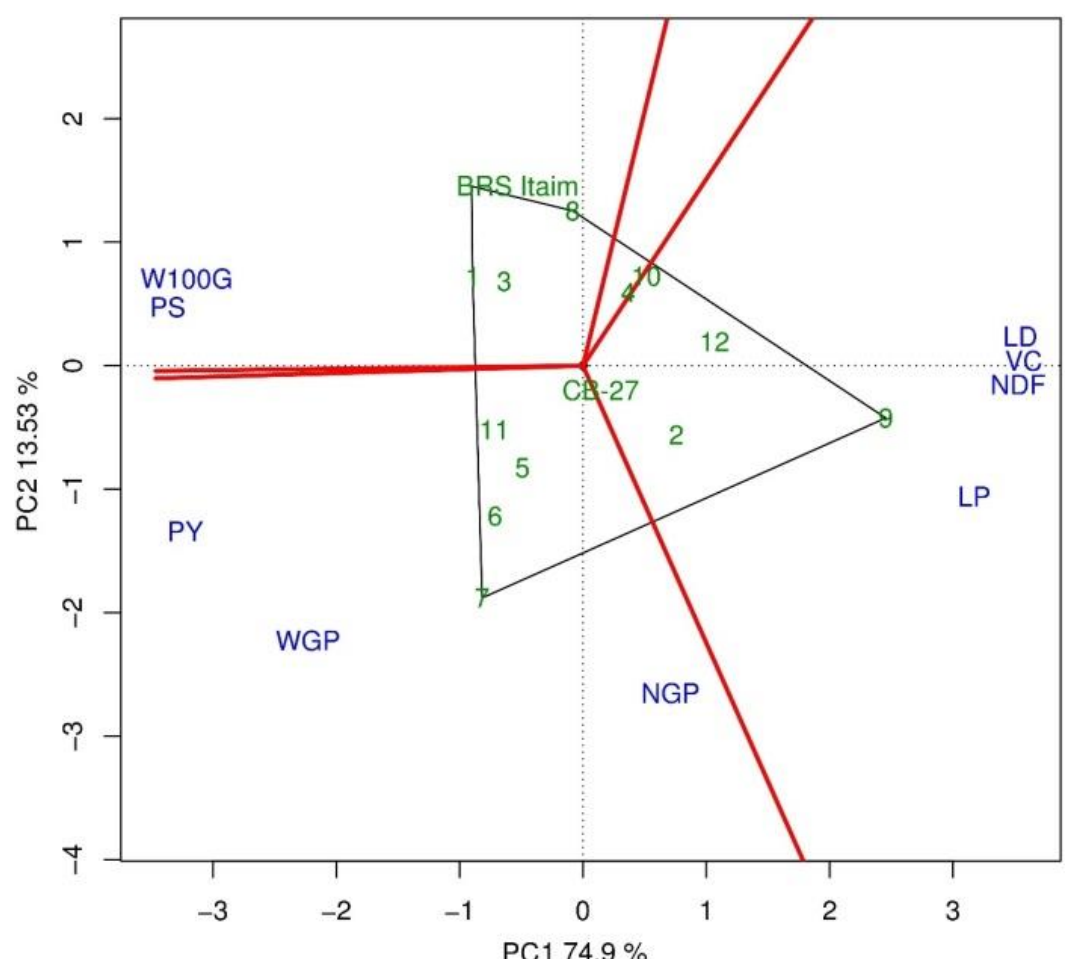

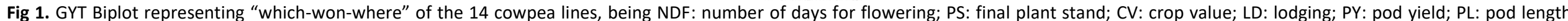

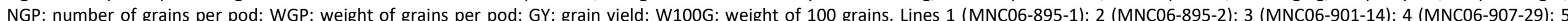
(MNC06-907-30); 6 (MNC06-907-35); 7 (MNC06-908-39); 8 (MNC06-909-52); 9 (MNC06-909-54); 10 (MNC06-909-55); 11 (MNC06-909-68); 12 (MNC06-909-76); 13 (BRS Itaim); 14 (CB-27). 


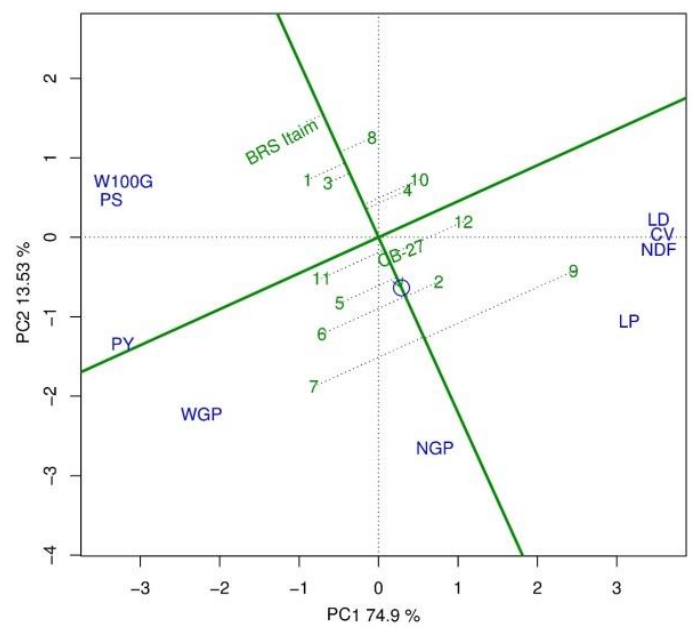

Fig 2. GYT Biplot representing average $\times$ trait, indicating the ranking of the 14 cowpea lines for 10 traits, being number of days for flowering (NDF); final plant stand (PS); crop value (CV); lodging (LD); pod yield (PY); pod length (PL); number of grains per pods (NGP); weight of grains per pod (WGP); grain yield (GY); and weight of 100 grains (W100G). Lines 1 (MNC06-895-1); 2 (MNC06-8952); 3 (MNC06-901-14); 4 (MNC06-907-29); 5 (MNC06-907-30); 6 (MNC06-907-35); 7 (MNC06-908-39); 8 (MNC06-909-52); 9 (MNC06-909-54); 10 (MNC06-909-55); 11 (MNC06-909-68); 12 (MNC06-909-76); 13 (BRS Itaim); 14 (CB-27).

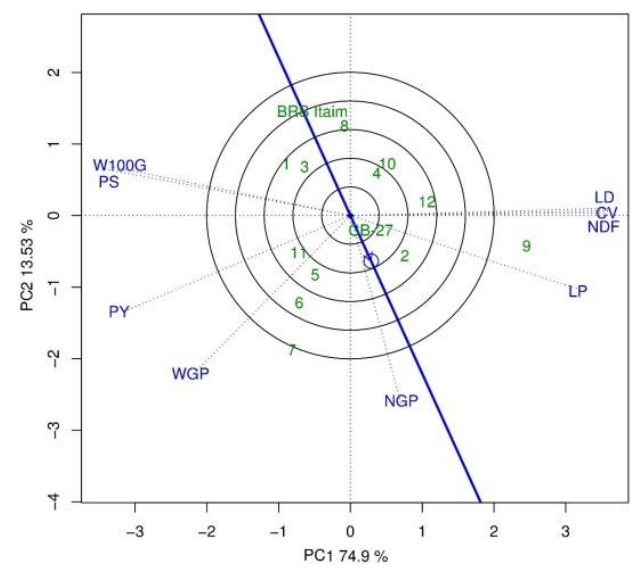

Fig 3. GYT Biplot describing the 14 lines and representing the best ones for each trait, being number of days for flowering (NDF); final plant stand (PS); crop value (CV); lodging (LD); pod yield (PY); pod length (PL); number of grains per pods (NGP); weight of grains per pod (WGP); grain yield (GY); and weight of 100 grains (W100G). Lines 1 (MNC06-895-1); 2 (MNC06-895-2); 3 (MNC06901-14); 4 (MNC06-907-29); 5 (MNC06-907-30); 6 (MNC06-907-35); 7 (MNC06-908-39); 8 (MNC06-909-52); 9 (MNC06-909-54); 10 (MNC06-909-55); 11 (MNC06-909-68); 12 (MNC06-909-76); 13 (BRS Itaim); 14 (CB-27).

Mean yield of the assessed strains, regarding the combination of yield characteristics, as well as their discriminant, were assessed based on partitioning the single value focused on genotype (ATC). The arrow inside the circle, in the average test axis (ATA), points to the highest strain value in all combinations of yield characteristics (Yan, 2018) (Figure 2).

The line perpendicular to ATA divides the strains presenting best performance (to the right) from the ones recording the worst performance (to the left). With regard to projections between strains and ATA, it is possible stating that the shorter the length, the more balanced is the combinations of characteristics. However, long projections indicate strains with the best or worst performances under specific combinations.

Thus, strains L9, L7, L2 and L6, within this particular order, recorded performance above the general mean for the assessed yield characteristics; therefore, they were better than the commercial cultivars. Strains L5, L11, L12 and cultivar BRS Itaim showed results within the general mean, whereas strains L1, L3, L4, L8, L10 and cultivar CB-27 presented worse results.
Based on discriminate, strains L2 and cultivar BRS Itaim, besides their good performance, presented stability in the set of combinations of yield characteristics in the MEGATARGET-TRAITS 2 group. Strains L9 and L12 recorded the

best estimates productive in the yield/value for MEGATARGET-TRAITS 1 . Similarly, strains L7 and L6 showed the best yield levels in the MEGA- TARGET-TRAITS 3. In each "mega- target-traits" there are greatest option of responsive strains for cultivation. Moreover, genetic variability can be generated to select superior progeny for a potential target trait. It is noteworthy that some strains outperformed the commercial cultivars. Strains recording the best performances in the set of yield characteristics could be used as parents in new enhancement programs focused on achieving genetic gains in the herein assessed variables. Oliveira et al. (2018) and Bishnoi et al. (2018) found betterperformance bean strains resulting from crossings between enhanced parents.

It is important measuring the representativeness of the target trait, if a trait is unrepresentative, it becomes useless and can provide biased information about the evaluated 
genotypes. A concentric circles in the biplot (Figure 3) help visualizing the length of traits vectors, which must be proportional to the standar deviation of the respective traits, besides being a better way to mesure the discrimination ability of the trait. The average trait is represented by the small circle at the end of the arrow, it presents the mean coordinates of all test traits. The middle trait axis (ATA) is the line crossing middle trait and biplot origen. Thus, a test trait presenting an angle smaller than ATA is more representative than the other traits. The number of grain per pod located in the mega-target-trait 2 is the most representative and has the discriminatory ability. Therefore, mega-target-trait 2 showed better genotype discrimination ability showing higher genotype variability expression in these traits, which allowed the accurate selection of beans for ideal performance in terms of yield related.

Identifying variables that allow selecting superior characteristics is a very important part of enhancement programs, since it can result in superior genotypes. Thus, assessing the correlation between variables allows learning to which extent a characteristic will be influenced by the others due to selection (PARAMESH, 2016).

Figure 3 depicts the correlations between sets of yield characteristics, depending on the angle established between the vectors of two sets of yield characteristics. Positive correlations are expressed by vectors forming an acute angle $\left(<90^{\circ}\right)$. Lack of correlation is represented by a right angle (=90). The obtuse angle (>90) expresses negative correlation and the 180 o angle represents strong negative correlation.

Thus, GY*CV had strong positive correlation to the yieldbedding, number of days required for flowering and pod length combinations. Andrade et al. (2010) concluded that value for cultivation has positive correlation to bedding; however, the correlation between bedding and pod length was negative.

The positive correlation between GY*W100G and GY*FP was explained by bean's fenotypic plasticity,i.e., beans have the ability to occupy empty spaces where the number of plants is smaller than the recommended, fact that makes grains heavier (Barili, 2011).

GY*PY and GY*GWP combinations also recorded positive correlation to $\mathrm{GY}^{*} 100 \mathrm{GW}$. Based on this outcome, such combination directly influenced gains in the pod yield/meangrain-weight-per-pod combination. Such results corroborated the findings by Andrade et al. (2010) and Correa et al. (2015).

One of the main dificulties faced by bean enhancement programs lies on finding strains presenting high performance in variables 'number of days required for flowering' and '100 grain weight' (CABRAL et al., 2011; DA SILVA; NEVES, 2011). Such difficulty is easily overcome when the GYT biplot methodology is applied, since it allows selecting strains presenting high yield in negateviley correlated characteristics.

\section{Materials and methods}

\section{Genotypes used in the study and experimental site}

Fourteen (14) black eyed cowpea bean strains were assessed between 2016 and 2017; two commercial cultivars were the witnesses (BRS Itaim and CB-27) (Table 1). The experiment was conducted in Bom Jesus de Itaboana County, Southeast Rio de Janeiro State, Brazil (Latitude $21^{\circ} 08^{\prime} 02^{\prime \prime S}$, longitude $41^{\circ} 40^{\prime} 47^{\prime \prime} \mathrm{W}$; altitude $\left.88 \mathrm{~m}\right)$. Mean temperature in the region is $23^{\circ} \mathrm{C}$, soil is classified as yellow red latosol + cambisol and the climate is tropical, according to Köppen-Geiger's classification (Alvares, 2013).

The experiment followed a completely randomized block design with four repetitions. Each plot had 4 lines (3m long), the two central rows were the usable area. Rows were spaced $0.5 \mathrm{~m}$ from each other and plants were sown $0.1 \mathrm{~m}$ from one another; thus, totaling 10 plants per meter and total population of 50 thousand plants per hectare.

\section{Analyzed variables}

The following characteristics were assessed: number of days required for flowering (NDF) - total number of days between sowing and flowering -; final stand (FS) - number of plants per plot; value for cultivation (VC) - assessed at the beginning of pod maturity, based on plants' general aspect, pod and grain characteristics, and on phytosanitary aspects; bedding (LD) - number of plants bedded per plot; pod yield (PY) - total weigh (in grams - g) of pods from each plant measured in precision scale; number of grains per pod (NGP) - mean number of grains per pod; grain weigh per pod (GWP) - total weight in grams (g) of grain/pod - measured in precision scale; grain weight (GW): total weight (in grams - g) of each grain, after pod threshing - measured in precision scale; pod length (PL): measured in centimeters $(\mathrm{cm})$ with graduated ruler; 100-grain weight (W100G) - weight of randomly-chosen 100 grains (measured in precision scale).

\section{Statistical analysis}

Analysis of variance took into account the effects of selected strains and growing years. The multivariable GYT biplot was conducted based on Yan and Frégeau-Reid (2018). For the GYT biplot multivariate analysis, the means of the grain yield combinations with the other variables were used, according to the methodology proposed by Yan and Frégeau-Reid (2018).

The principal component (PC) analysis was used to assess the means of sets of yield variables based on the recorded values.

Biplot graphs were generated from values recorded for the two principal components. The first one (PC1) is represented in the horizontal axis and the second, (PC2) in the vertical axis.

The R software (R Development Core Team, 2014) - package ggplot2 (Wickham, 2009), was used for the analysis of variance and to plot the GYT biplot graphs.

\section{Conclusion}

The GYT biplot is an instrument easy to handle, besides allowing the simultaneous selection of two characteristics. Strains L9, L7 and cultivar BRS Itaim recorded the best yield regarding the assessed variables. The yield/pod-lenght combination led to indirect gains in the other sets of yield characteristics.

\section{Acknowledgements}

This study was financed in party by the Coordenação de Aperfeiçoamento de Pessoas de Nível Superior -Brasil (CAPES)- Finance Code 001. In addition, I would like to thank FAPERJ and CNPq for the scholarship granted to the scholars. 


\section{Authenticity confirmation}

The authors confirm that no parts of this manuscript has been published or under publication or submitted in any form and anywhere,

\section{References}

Alvares CA, Stape JL, Sentelhas PC, Moraes G, Leonardo J, Sparovek G (2013) Köppen's climate classification map for Brazil. Meteorol Z. 22:711-728

Andrade FN, Rocha MDM, Gomes RLF, Freire Filho FR, Ramos SRR (2010) Estimativas de parâmetros genéticos em genótipos de feijão-caupi avaliados para feijão fresco. Rev Ciênc Agron. 41:253-258.

Barili DL, Vale NM, Morais PPP, Baldissera JNC, Almeida CB, Rocha F, Valentini G, Bertoldo JG, Coimbra JLM, Guidolin AF (2011) Correlação fenotípica entre componentes do rendimento de grãos de feijão comum (Phaseolus vulgaris L.). Semina: Ciênc Agrár. 32:1263-1274.

Bishnoi SK, Hooda JS, Sharma P, Kumar P (2018) Analysis of combining ability and inheritance of breeding parameters in yield component traits in faba bean (Vicia faba L.). J Pharmacogn Phytochem. 7:1085-1090.

Bomfim-Silva EM, Soares DC, Silva PCL, Damasceno APA, Da Silva TJA, Souza HHF (2018) Initial development of cowpea bean fertilized with natural phosphate in the brazilian cerrado soil. Am J Plant Sci. 9:1381-1390.

Cabral PDS, Soares TCB, Lima ABP, Soares YJB, Silva JA (2011) Análise de trilha do rendimento de grãos de feijoeiro (Phaseolus vulgaris L.) e seus componentes. Rev Ciênc Agron. 42:132-138.

Coelho CG (2017) Parâmetros genéticos e absorção de nutrientes de feijão-comum em competição com planta daninha. Thesi presented at the Universidade Federal do Espírito Santo, Espírito Santo, February, 2017.

Correa AM, Ceccon G, Correa CMA, Delben DS (2015) Estimativas de parâmetros genéticos e correlações entre caracteres fenológicos e morfoagronômicos em feijãocaupi. Ceres. 59:87-94.

Cruz CD, Carneiro PCS (2014) Modelos biométricos aplicados ao melhoramiento genético. UFV, Viçosa.

Da Silva JAL, Neves JA (2011) Componentes de produção e suas correlações em genótipos de feijão-caupi em cultivo de sequeiro e irrigado. Rev Ciênc Agron. 42:702-713.

Freire Filho FR (2011) Feijão-caupi no Brasil: produção, melhoramento genético, avanços e desafios. Embrapa, Brasília.
Gonçalves JGR (2013) Identificação de linhagens de feijoeiro (phaseolus vulgaris I.) tolerantes à seca. Thesi presentedd at the Instituto Agronômico de Campinas, São Paulo, March, 2013.

IBGE- Instituto Brasileiro de Geografia e Estatística (2017) Estatística da Produção Agrícola Setembro de 2017. https://ww2.ibge.gov.br/home/estatistica/indicadores/agr opecu aria/Ispa/Ispa 201709 6.shtm (accessed 13 august 2018).

MAPA- Ministério da Agricultura, Pecuária e Abastecimento (2017) CultivarWeb. Cultivares registradas. Feijãocaupi/Feijão-fradinho/ Feijão-miúdo/Feijão-de-corda (Vigna unguiculata (L.) Walp.). http://extranet.agricultura.gov.br/php/proton/ cultivarweb/cultivares_registradas.php. Aaccessed 13 Aug 2018

Oliveira TRA, Gravina GA, Oliveira GHF, Araújo LC, Araújo KC, Cruz DP, Amaral Junior AT, Vivas M, Daher RF (2018) Multivariate analysis used as a tool to select snap bean (Phaseolus vulgaris L.) genotypes. Aust J Crop Sci. 12:6773.

Oliveira TRA, Gravina GA, Rocha MM, Alcântara Neto F, Cruz DP, Oliveira GHF, Sant'Anna CQSS, Jaeggi MEPC, Rocha RS (2019) J Exp Agric Int. 41: 1-9.

Paramesh M, Reddy D, Priya MS, Sumathi P, Sudhakar P, Reddy K (2016) GT biplot analysis for yield and drought related traits in mung bean (Vigna radiata L. Wilczek). Electron. J Plant Breed. 7:538-543.

Pimentel-Gomes F, Garcia CH (2002) Estatística aplicada a experimentos agronômicos e florestais: exposição com exemplos e orientações para uso de aplicativos. Fealq, Piracicaba.

Santos JD (2013) Produtividade de cultivares de feijão-caupi no Agreste Paraibano. Rev Tecnol Ciên Agropec. 7:31-36.

Santos MH (2013) Melhoramento do feijão-de-vagem: herança da resistência a Xanthomonas axonopodis $p v$. phaseoli e potencial agronômico de linhas parcialmente endogâmicas obtidas pelo método ssd. Thesi presented at the Universidade Estadual do Norte Fluminense Darcy Ribeiro, Rio de Janeiro, Mach, 2013.

Wickham, H (2009) ggplot2: Elegant Graphics for Data Analysis. Springer, New York.

Yan W (2001) GGEbiplot-a Windows application for graphical analysis of multienvironment trial data and other types of two-way data. Agron. J. 93:1111-1118.

Yan W, Frégeau-Reid J (2018) Genotype by Yield* Trait (GYT) Biplot: a Novel Approach for Genotype Selection based on Multiple Traits. Sci Rep. 8:1-10. 